\title{
Evaluation of spray deposits with twin flat tip with air induction in two soybean stages
}

\author{
Evaluación de los depósitos de pulverización con punta plana \\ doble con inducción de aire en dos etapas de soja
}

\author{
Fábio Henrique Rojo Baio ${ }^{1 *}$, Anderson Luiz Pettenan ${ }^{1}$, Herivelton da Silva Camolese ${ }^{1}$, \\ Raul Rodolfo Francischetti Gabriel ${ }^{1}$
}

\begin{abstract}
Fungicide application for soybean rust control forced farmers to upgrade the techniques of pesticide application. This study aimed to compare the spray deposits obtained by two spray tips, flat fan and twin flat spray tip with air induction, with and without the presence of adjuvant in the tank solution, in three regions of the plant canopy and at two different crop growth stages. The soybean crop evaluated was P98Y11RR at growth stages R1 and R5.2. Leaf deposits of the spray mix containing Rhodamine B as tracer dye were recovered from the canopy stratum and analyzed. The use of double fan spray tip with air induction resulted in higher levels of droplet deposit in the upper canopy stratum of soybean plants in the R1 and R5.2 growth stages, and can also replace the standard flat fan tip with the same level of spray deposits on the lower canopy region. The use of adjuvant increased spray deposits in all sections of the plant, with both spray tips in the R1 growth stage.
\end{abstract}

Key words: spray tips, application technology, tracer dye.

\section{RESUMEN}

La aplicación de fungicidas para el control de roya de la soja obligó a los agricultores a mejorar las técnicas de los métodos de aplicación de plaguicidas. Este estudio tuvo como objetivo comparar los depósitos de pulverización obtenidos por dos puntas de pulverización, abanico plano y la boquilla de pulverización plana doble con inducción de aire, con y sin la presencia de adyuvante en la solución del tanque, en tres regiones de la copa de la planta, ya las dos de crecimiento del cultivo diferentes etapas. La cosecha de soja P98Y11RR fue evaluado en las etapas de crecimiento R1 y R5.2. Los depósitos de la hoja de la mezcla de pulverización que contiene Rodamina B como colorante trazador se recuperaron a partir del estrato de dosel y analizados. Se concluyó que el uso de la punta de pulverización de doble ventilador con inducción de aire resultó en mayores niveles de depósito de gotas en el estrato de dosel superior de las plantas de soja en las etapas de crecimiento R1 y R5.2, y también puede reemplazar el consejo estándar de abanico plano con el mismo nivel de depósitos de aspersión en la región inferior del dosel. El uso de adyuvante aumenta los depósitos de aspersión en todas las secciones de la planta, a pesar de las puntas de pulverización utilizados, cuando la aplicación se produjo en la etapa de crecimiento R1.

Palabras clave: punta de pulverización, técnica de aplicación, trazadores químicos.

\section{Introduction}

The recent increase in soybean (Glycine max) production cost is due in part to the greater frequency of application of pesticides, especially fungicides to control rust, which initially attacks the lower section of the plants, making it more difficult to control (Meneghetti et al., 2010). According to Navarine et al. (2007), Asian soybean rust can cause losses from $10 \%$ up to $75 \%$ compared to the expected productivity if the control is not performed efficiently.

According to Balardin et al. (2015), penetration of droplets inside the plant canopy depends on several factors, mainly weather conditions, leaf area and plant architecture. Raetano (2007) stated that the fungicide must overcome the barrier imposed by the leaves and provide great coverage in the lower parts of the canopy. For Antuniassi and Baio (2009), application success and the control

1 UFMS, Chapadao do Sul, MS, Brazil.

* Corresponding Autor: fabiobaio@ufms.br.

Fecha de Recepción: 21 Mayo, 2016.

Fecha de Aceptación: 20 Julio, 2016.

DOI: $10.4067 /$ S0718-34292016005000018 
results are directly linked to the following factors: application technique, adjustment of the application rate, operating parameters, favorable environmental conditions, correct timing of application, and especially the selection of the spray tip. The tip most frequently used to apply fungicides is the standard flat fan, which produces from medium to very fine droplets and is prone to losses due to drift (Ferreira et al., 2011). For this reason some people have attempted to use tips that produce larger droplets such as the pre-orifice flat fan, the air induction flat fan and the twin flat fan with air induction (Cunha and Ruas, 2006).

The use of adjuvants is an alternative that reduces spray loss by drift and increases drop persistence in the environment (Cunha et al., 2010). But according to Aguiar Junior (2011) and Araújo and Raetano (2011), adjuvants should be used with caution, because the several benefits of their use creates uncertainty and discussion, due to misuse, applicable laws or even by the lack of knowledge of the interaction between adjuvants and active ingredients. For instance, Cunha et al. (2010) observed that four different adjuvants did not affect the spectrum uniformity of sprayed droplets, but noted that the effect of adjuvants in the droplets' spectrum was dependent on the spray tip and the agrochemical used.

In the 1980s and 1990s application rates greater than $200 \mathrm{~L} \mathrm{ha}^{-1}$ were used in soybean crops, over-wetting the crop canopy, often causing agrochemical losses due to runoff and environmental contamination. This procedure also reduces the sprayers' operational field capacity. Currently, the trend is to a reduction of the application rate, thereby increasing the sprayers' autonomy and operational field capacity and reducing the application cost (Cunha et al., 2008; Cunha; Peres, 2010; Roman et al., 2009). Therefore, more studies are needed to understand the acceptable spray deposits inside the crop canopy with the use of adjuvants.

According to Boschini et al. (2008), the study of the spray deposits can be applied with natural or artificial targets, as the most used method, and can explain several factors related to pesticide spray deposition. However, the cost of analysis is high when the agrochemical is measured directly. For this reason, the use of tracer dye added to the sprayer tank is attractive. Baio et al. (2011) evaluated the tracer dye Rhodamine B added to the pesticide sprayer tank to quantify spray drift in aerial application, and concluded that this tracer dye can be used effectively to evaluate spray deposits.

Thus, it is important to verify whether the use of a spray tip not commonly used on soybean crops that produces larger droplets with lower risk of drift (Gandolfo et al., 2013), such as the twin flat fan with air induction associated with the use of adjuvants, does not compromise the spray deposits within the soybean crop canopy. This study aimed to compare the spray deposits obtained by two spray tips, flat fan and twin flat spray tip with air induction, with and without the presence of adjuvant in the tank solution, in three regions of the plant canopy and at two different crop growth stages.

\section{Materials and Methods}

The experimental plots measuring 25 by $6 \mathrm{~m}$ were installed in a soybean crop field located in Chapadão do Sul/MS/Brazil. The field area was 92 ha in the Campo Bom Farm, at an average elevation of $820 \mathrm{~m}$, with geographic coordinates $18^{\circ} 46^{\prime} 46.93^{\prime \prime}$ south latitude and $52^{\circ} 37^{\prime} 38.64^{\prime \prime}$ west longitude.

The soybean crop was conducted in a no-till system, covered by crop residues from the 2010/2011 corn crop, with row spacing of $0.50 \mathrm{~m}$ and plant population established with 240,000 plants ha ${ }^{-1}$. The soybean crop used was P98Y11 from Pioneer Seeds, with a crop cycle of 120 days. The first spray application of the experiment was conducted when the soybean was beginning to flower (growth stage $\mathrm{R} 1$ ), with an average plant height of $0.68 \mathrm{~m}$. At the second spray application, the soybean was in the R5.2 growth stage (full flowering), with an average plant height of $1.0 \mathrm{~m}$.

The experiment was conducted in a randomized block design with four replications in a $2 \times 2 \times 3$ factorial; the factors were spray nozzles (flat fan and twin flat spray tip with air induction); adjuvant (presence or absence); and plant canopy strata (upper, middle and lower). The experiment was evaluated in two growth stages using the same experimental design. The data obtained from the experiment were submitted to the ShapiroWilk normality test and then to ANOVA. Significant effects from the F test were discriminated using the Tukey test $(\mathrm{p}<0.05)$ to compare multiple means using the SISVAR software.

Spray application was performed using a Herbicat model backpack sprayer pressured by $\mathrm{CO}_{2}$ (Catanduva, SP, Brazil), with six nozzles spaced at $0.50 \mathrm{~m}$ from each other. The sprayer was calibrated 
prior to the application; the application rate was 120 $\mathrm{L} \mathrm{ha}^{-1}$ in all replications. The spray tips used on the nozzles were Jacto AVI Twin 110 with dual fan and air induction, in order to obtain larger drops, and Jacto AXI 110 with a standard plane fan, in order to obtain medium size drops. The sprayer was pressurized at $310.05 \mathrm{kPa}$, applying at $2.22 \mathrm{~m} \mathrm{~s}^{-1}$.

For all replications, $2 \mathrm{~L}$ of the basic spray mixture were prepared in plastic bottles containing rhodamine $\mathrm{B}$ at a concentration of $40 \mathrm{mg} \mathrm{L}^{-1}$. Two treatments included the surfactant adjuvant LI $700^{\circledR}$ (phosphatidylcholine and propionic acid) manufactured by De Sangosse Agroquímica LTDA at a concentration of $5 \mathrm{~mL} \mathrm{~L}^{-1}$, as recommended by the manufacturer.

Two glass plates of $0.019 \mathrm{~m}^{2}$ each were used as artificial targets above the canopy and placed in each plot in order to obtain the reference deposit of the tracer dye and to evaluate the effect of spray drift; although it had been minimized, it could be altogether eliminated and thus compromise the analyses. Water-sensitive paper was placed on the plots to monitor the droplet size produced by each treatment. The applications were performed in the early morning to minimize the interference of wind, temperature and sunlight (Antuniassi and Baio, 2009). The environmental data were recorded every five minutes during the applications. The distance between the spray nozzle and the crop canopy was $0.50 \mathrm{~m}$. An Instrutherm AD-250 portable digital anemometer and an Instrutemp TH802A thermohygrometer were used.

After the application of the treatments in each soybean growth condition, the glass plates were collected and stored in plastic containers; the watersensitive paper was also collected and stored in plastic bags. Subsequently, 3 trifoliate leaves were collected from each position of the 3 canopy strata in 4 soybean plants from the central regions of the plots, totaling 36 trifoliate leaves per treatment and 432 trifoliate leaves in each evaluated growth stage.

The tracer dye extraction process from the leaves utilized a solution of distilled water and $1 \%$ Tween 80 . The bags containing the leaf samples were sealed and placed on a Tecnal ET- 45 orbital shaker at 120 RPM for two hours, in a dark environment to avoid degradation of the tracer dye (Baio et al., 2011). Each extracted solution was read with a calibrated Turner Designs Trilogy fluorimeter (Sunnyvale, CA, USA). The reading results were in micrograms per liter of solution, which was converted to micrograms per leaf sample area of each trifoliate leaf. The glass plates also were subjected to extraction of the tracer dye using the same method.

The trifoliate leaves were scanned at $300 \mathrm{dpi}$ resolution on an HP Deskjet F4280 flatbed scanner. The software ImageJ 1.45 was used to measure the leaf area digitally (Bauermann, 2015). The watersensitive papers were scanned at 600 dpi resolution and the drop size was evaluated with the aid of the Gotas software (Embrapa, 2015).

\section{Results and Discussion}

During the spray application conducted at the $\mathrm{R} 1$ growth stage, the lowest and highest temperatures ranged between $24^{\circ} \mathrm{C}$ and $28^{\circ} \mathrm{C}$, the relative humidity ranged between $68 \%$ and $85 \%$, and the wind speed was between 2.8 and $9.7 \mathrm{~km} \mathrm{~h}^{-1}$. The variation in these observed conditions could have influenced the experimental results (Antuniassi and Baio, 2009) if the treatments had not been randomized. Over the replications, the average droplet size measured by the AXI flat fan tip was $304.0 \mu \mathrm{m}$ and the average obtained by the AVI Twin dual fan air induction tip was $740.2 \mu \mathrm{m}$.

The result of the ANOVA showed that the interaction between the three factors (spray tip, adjuvant and canopy stratum) was not significant at $5 \%$ probability ( $\mathrm{F}$ test). Table 1 presents the data of the interaction between the spray tip and the plant canopy stratum, indicating that regardless of the spray tip, there was greater deposition in the upper plant canopy stratum, where there was greater deposition of tracer dye in relation to the other regions, agreeing with Villalba et al. (2009), who also studied the spray deposition in a soybean crop at the $\mathrm{R} 1$ growth stage. The dual fan air induction spray tip provided greater deposit level in the upper canopy stratum and less deposit in the middle stratum, but the deposits

Table 1. Average tracer dye deposition $\left(\mu \mathrm{L} \mathrm{cm}{ }^{-2}\right)$ obtained by the different spray tips in different canopy strata of the plant in growth stage R1.

\begin{tabular}{lccc}
\hline Spray Tip & Upper & Middle & Lower \\
\hline AXI & $16.96 \mathrm{Ab}$ & $6.99 \mathrm{Ba}$ & $2.54 \mathrm{Ca}$ \\
AVI Twin & $21.72 \mathrm{Aa}$ & $6.46 \mathrm{Bb}$ & $2.56 \mathrm{Ca}$ \\
\hline
\end{tabular}

Means followed by different letters, lower case for columns and upper case for rows, differ by the Tukey test at a 5\% probability level. Minimum Significant Difference $=0.41 \mu \mathrm{L} \mathrm{cm}{ }^{-2} . \mathrm{CV}=$ $5.87 \%$. Overall mean $=10.17 \mu \mathrm{L} \mathrm{cm}^{-2}$. 
obtained in the lower stratum were equal. Thus, the double fan air induction spray tip, used mainly to reduce spray drift by producing larger droplets, deposited more in the upper stratum. However, under the experimental conditions this spray tip also generated a certain amount of smaller droplets that managed to deposit the same quantity of spray in the lower canopy stratum, the plant region where Asian soybean rust starts to establish itself. According to Cunha et al. (2008), air induction tips generate large drops that can hinder good penetration, therefore its use should be carefully considered.

Comparing different spray tips with different application rates in different strata of the soybean CD 202 cultivar, Boschini et al. (2008) noted that deposition in the middle and lower strata was significantly lower compared to the upper stratum regardless of the tip or application rate used. Studying the effect of spray tip in the chemical control of soybean rust, Cunha et al. (2006) reported that coverage was quite uneven due to the crop leaf density. Antuniassi et al. (2004) found that the worst deposition results in the lower stratum of soybean plants were obtained using air induction tips. Cunha and Peres (2010) found no difference in droplet deposition in the upper and middle canopy strata, whether they used a deflector tip, a twin flat tip or a twin flat tip with air induction, which produce medium-thick, fine-medium, and very thick droplets, respectively, showing that an air induction tip can often have the same deposition performance obtained by a tip that produces finemedium droplets. All these authors used 200 and $250 \mathrm{~L} \mathrm{ha}^{-1}$ of application rate, while the current trend is to reduce this rate to levels such as the 120 $\mathrm{L} \mathrm{ha}^{-1}$ applied in the present study.

The differences reported in published studies indicate that there is a need to establish a similar methodology for comparative purposes, since the evaluation of the deposition can be strongly influenced by weather conditions, influencing the spray drift, which in turn interferes with the response variable, the deposition. This deposition also depends on the plant's architecture and leaf area index, which in turn is dependent on the genetic material. Furthermore, deposition may be influenced by droplet size, which depends on the tip model and the pressure used. Finally, deposition may be dependent on the application rate; the lower the rate, the smaller the amount of fine droplets that will be generated, and the greater the chance that they will be intercepted by the plant mass of the upper and middle canopy strata.

Table 2 presents the results of the interaction between the spray tip and the use of adjuvant. AVI Twin tip with air induction showed the highest deposition on soybean leaves when the mixture included adjuvant. Also, the average deposition was higher for both spray tips when the adjuvant was present in the spray. Similar results were obtained by Aguiar Júnior et al. (2011) testing adjuvants and air assistance in the sprayer boom related to the spray deposits and control of Asian soybean rust. Lemos et al. (2011) found that the use of vegetable oil in the spray mixture applied by a TT sprayer tip resulted in a reduction of the potential spray drift risk. Evaluating the performance of oil adjuvants over the aerial spray, Silva et al. (2011) found no difference in direct comparison between applications of mineral oil or emulsified vegetable oil in the deposition of the upper and middle canopy strata, but deposition in the lower stratum was better with the application of mineral oil.

In the upper canopy stratum (Table 3), deposition was higher when sprayed without the adjuvant. In the middle and lower canopy strata, the plant regions where the soybean rust control target is located, the average deposition was higher when the adjuvant was added to the spray mixture. Miller and

Table 2. Average tracer dye deposition $\left(\mu \mathrm{L} \mathrm{cm}^{-2}\right)$, obtained by the different spray tips in the presence and absence of the adjuvant in growth stage R1.

\begin{tabular}{lcc}
\hline Spray Tip & With Adjuvant & Without Adjuvant \\
\hline AXI & $9.62 \mathrm{Ab}$ & $8.04 \mathrm{Bb}$ \\
AVI Twin & $10.49 \mathrm{Aa}$ & $10.01 \mathrm{Ba}$ \\
\hline
\end{tabular}

Means followed by different letters, lower case for columns and upper case for rows, differ by the Tukey test at a $5 \%$ probability level. Minimum Significant Difference $=0.28 \mu \mathrm{L} \mathrm{cm}^{-2}$.

Table 3. Average tracer dye deposition $\left(\mu \mathrm{L} \mathrm{cm}{ }^{-2}\right)$ obtained by the presence and absence of the adjuvant in the different canopy strata of the plant in growth stage R1.

\begin{tabular}{lccc}
\hline & Upper & Middle & Lower \\
\hline With Adjuvant & $19.09 \mathrm{Ab}$ & $8.26 \mathrm{Ba}$ & $2.81 \mathrm{Ca}$ \\
Without Adjuvant & $19.59 \mathrm{Aa}$ & $5.18 \mathrm{Bb}$ & $2.29 \mathrm{Cb}$ \\
\hline
\end{tabular}

Means followed by different letters, lower case for columns and upper case for rows, differ by the Tukey test at a $5 \%$ probability level. Minimum Significant Difference $=0.34 \mu \mathrm{L} \mathrm{cm}^{-2}$. 
Butler-Ellis (2000) argue that the droplets formed by the tips with air induction technology are more sensitive to changes in the physical properties of the spray when forming the droplets, which is precisely what occurs when the adjuvant is added. In a similar study, Cunha and Peres (2010) observed no increase in the deposition in the lower stratum. The effects of adjuvants vary greatly according to each application situation. In this study, its use may have improved the scattering and dispersion of the spray, providing a better distribution of the spray in the plant profile.

During the spray application conducted at the R5.2 growth stage the temperature ranged between $26.9^{\circ} \mathrm{C}$ and $35.5^{\circ} \mathrm{C}$, the relative humidity ranged from $68 \%$ to $43 \%$, and the wind speed was between 2.7 and $7.7 \mathrm{~km} \mathrm{~h}^{-1}$. The result of the variance analysis showed that the interaction between the three factors (spray tip, adjuvant and canopy stratum) was not significant at $5 \%$ probability ( $\mathrm{F}$ test) at this growth plant stage.

As in the application at R1, there was no significant difference of the deposits formed by the two tips in the mean deposition levels in the lower stratum (Table 4). However, unlike the previous assessment, there was also no significant difference between the two tips related to the deposition in the middle stratum, showing that differences in plant architecture and leaf area index may interfere with the final result of the spray deposition, even for the same genetic material, as previously reported. The deposition in the upper stratum was also repeated, showing higher deposits of droplets from the AVI twin tip with air induction, whose deposition was

Table 4. Average tracer dye deposition $\left(\mu \mathrm{L} \mathrm{cm}^{-2}\right)$ obtained by the different tips in different strata of the plant in growth stage R5.2.

\begin{tabular}{lccc}
\hline Spray Tip & Upper & Middle & Lower \\
\hline AXI & $21.27 \mathrm{Ab}$ & $3.37 \mathrm{Ba}$ & $1.37 \mathrm{Ca}$ \\
AVI Twin & $24.88 \mathrm{Aa}$ & $2.73 \mathrm{Ba}$ & $1.02 \mathrm{Ca}$ \\
\hline
\end{tabular}

Means followed by different letters, lower case for columns and upper case for rows, differ by the Tukey test at a $5 \%$ probability level. Minimum Significant Difference $=1.27 \mu \mathrm{L} \mathrm{cm}{ }^{-2} . \mathrm{CV}=$ $23.14 \%$. Overall mean $=9.57 \mu \mathrm{L} \mathrm{cm}^{-2}$.
$14.5 \%$ greater than that obtained with the flat fan tip. Studying the spray deposition in two soybean cultivars, Farinha et al. (2009) obtained deposits in the upper stratum that were nearly three times higher than in the middle and lower strata.

Unlike what occurred in the spray application in the R1 growth stage, the presence of the adjuvant in the spray in the R5.2 growth stage did not influence the deposition in the middle and lower strata (Table 5). The difference was only in the upper stratum, and it was higher due to the use of the adjuvant in the spray. This also may have occurred because of different pant architecture, increasing the droplet interception area in this region of the plant. Thus the leaf area index related to the crop growth stage seems to be important when comparing spray deposit results from different plant stages. Studying the droplet deposition and chemical control of soybean rust, Tormen et al. (2012) suggested that the leaf area index is an important factor in the effectiveness of the application. However, the change in this index alone cannot explain the variations in droplet deposition among different strata.

Table 5. Average tracer dye deposition $\left(\mu \mathrm{L} \mathrm{cm}^{-2}\right)$ obtained by the presence and absence of the adjuvant related to the different strata of the plant in growth stage R5.2.

\begin{tabular}{lccc}
\hline & Upper & Middle & Lower \\
\hline With Adjuvant & $24.82 \mathrm{Aa}$ & $3.37 \mathrm{Ba}$ & $1.38 \mathrm{Ca}$ \\
Without Adjuvant & $21.32 \mathrm{Ab}$ & $2.72 \mathrm{Ba}$ & $1.00 \mathrm{Ca}$ \\
\hline
\end{tabular}

Means followed by different letters, lower case for columns and upper case for rows, differ by the Tukey test at a 5\% probability level. Minimum Significant Difference $=1.52 \mu \mathrm{L} \mathrm{cm}^{-2}$.

\section{Conclusions}

The use of the twin flat spray tip with air induction resulted in higher levels of droplet deposit in the upper canopy stratum of soybean plants in the R1 and R5.2 growth stages, and also can replace the standard flat fan tip with the same level of spray deposits on the lower canopy region.

The use of adjuvant increased the spray deposits in all sections of the plant with both spray tips when applied in the R1 growth stage. 


\section{Literature Cited}

Aguiar Júnior, H.O.; Raetano, C.G.; Prado, E.P.; Pogetto, M.H.F.A.D; Christovam, F.S.; Gimenes, M.J.

2011. Adjuvantes e assistência de ar em pulverizador de barras sobre a deposição da calda e controle de Phakopsora pachyrhizi (Sydow \& Sydow). Summa Phytopathologica, Botucatu, 37, 3: 103-109.

Antuiniassi, U.R.; Baio, F.H.R.

2009. Tecnologia de aplicação de defensivos. In: Vargas, L.; Roamn, E.S., editors, Manual de manejo e controle de plantas daninhas. Embrapa Trigo, Passo Fundo. p. 173-212.

Antuniassi, U.R.; Camargo, T.V.; Bonelli, A.P.O.; Romagnole, H.W.C.

2004. Avaliação da cobertura de folhas de soja em aplicações terrestres com diferentes tipos de pontas. Paper presented at: Simpósio internacional de tecnologia de aplicação de agrotóxicos, 3. Proceedings. FEPAF, Botucatu, p. 48-51.

Araújo, D.; Raetano, C.G.

2011. Adjuvantes de produtos fitossanitários. In: Antuniassi, U.R., Boller, W., editors, Tecnologia de aplicação para culturas anuais. Aldeia Norte, Passo Fundo. p. 27-49.

Baio, F.H.R.; Borges, M.C.R.; Pettenan, A.L.; Antuniassi, U.R.

2011. Avaliação do uso e recuperação do pigmento rodamina utilizado como marcador em ensaios de deriva. Paper presented at: Simpósio Internacional de Tecnologia de Aplicação de Agrotóxicos, 5. Proceedings. FEPAF, Botucatu, p. 1-4.

Balardin R.; Madalosso, M.; Debortoli, M.; Lenz, G.

2015. Factors affecting fungicide efficacy in the tropics. [Online]. Available at: http://www.intechopen.com/books/fungicides/ factors-affecting-fungicide-efficacy-in-the-tropics.

Bauermann, G.

2015. Como usar o ImageJ. [Online]. Available at: http:// www.imagesurvey.com.br/2009/02/como-usar-o-imagej.

Boschini, L.; Contiero, R.L.; Macedo Júnior, E.K.; Guimarães, V.F.

2008. Avaliação da deposição da calda de pulverização em função da vazão e do tipo de bico hidráulico na cultura da soja. Acta Scientiarum Agronomy, 30, 2: 171-175.

Cunha, J.P.A.R.; Ruas, R.A.A.

2006. Uniformidade de distribuição volumétrica de pontas de Pulverização de jato plano duplo com indução de ar. Pesquisa Agropecuária Tropical, 36, 1: 61-66.

Cunha, J.P.A.R.; Moura, E.A.C.; Silva Júnior, J.L.; Zago, F.A.;

Juliatti, F.C.

2008. Efeito de pontas de pulverização no controle químico da ferrugem da soja. Engenharia Agrícola, 28, 2: 283-291.

Cunha, J.P.A.R.; Bueno, M.R.; Ferreira, M.C.

2010. Espectro de gotas de pontas de pulverização com adjuvantes de uso agrícola. Planta Daninha, 28: 1153-1158.

Cunha, J.P.A.R.; Peres, T.C.M.

2010. Influência de pontas de pulverização e adjuvante no controle químico da ferrugem asiática da soja. Acta Scientiarum Agronomy, 32, 4: 597-602.

Embrapa.

2015. Software Gotas. [Online]. Available at: http://www. cnpma.embrapa.br/novidades/sof_gota.html

Farinha, J.V.; Martins, D.; Costa, N.V.; Domingos, V.D.

2009. Deposição da calda de pulverização em cultivares de soja no estádio R1. Ciência Rural, 39, 6: 1738-1744.
Ferreira, M.C.I.; Lohmann, T.R.; Campos, A.P.; Viel, S.R.; Figueiredo, A.

2011. Distribuição volumétrica e diâmetro de gotas de pontas de pulverização de energia hidráulica para controle de corda-de-viola. Planta Daninha, 29, 3: 697-705.

Gandolfo, M.A.; Chechetto, R.G.; Carvalho, F.K.; Gandolfo, U.D.; Moraes, E.D.

2013. Influência de pontas de pulverização e adjuvantes na deriva em caldas com glyphosate. Revista Ciência Agronômica, 44, 3: 474-480.

Lemos, R.E.; Campos, H.B.; Ferreira, M.C.

2011. Parâmetros relacionados ao tamanho de gotas em dois modelos de pontas e diferentes concentrações de adjuvante. Paper presented at: Simpósio Internacional de Tecnologia de Aplicação de Agrotóxicos, 5. Proceedings. FEPAF, Botucatu, p. 1-4

Meneghetti, R.C.; Balardin, R.S.; Corte, G.D.; Favera, D.D.; Debona, D.

2010. Avaliação da ativação de defesa em soja contra Phakopsora pachyrhizi em condições controladas. Ciência e Agrotecnologia, 34, 4: 823-829.

Miller, P.C.H. and Buttler-Ellis, M.C.

2000. Effects of formulation on spray nozzle performance for applications from ground-based boom sprayers. Crop Protecion, 19, 1: 609-615.

Navarini, L.; Dallagnol, L.J.; Balardin, R.S.; Moreira, M.T.;

Meneghetti, R.C.; Madalosso, M.G.

2007. Controle químico da ferrugem asiática (Phakopsora pachyrhizi Sydow) na cultura da soja. Summa Phytopathologica, 33, 2: 182-186.

Raetano, C.G.

2007. Assistência de ar e outros métodos de aplicação a baixo volume em culturas de baixo fuste: a soja como modelo. Summa Phytopathologica, 33: 105-106.

Raetano, C.G.

2011. Assistência de ar em pulverizadores de barras: interferências e potencial de uso no sistema de plantio direto. In: Antuniassi, U. R., Boller, W., editors, Tecnologia de aplicação para culturas anuais. Aldeia Norte, Passo Fundo. p. 105-122.

Román, R.A.A.; Cortez, J.W.; Ferreira, M.C.; Oliveira, J.R.G. 2009. Cobertura da cultura da soja pela calda fungicida em função de pontas de pulverização e volumes de aplicação. Scientia Agraria, 10, 3: 223-232.

Silva, A.C.A.; Antuniassi, U.R.; Mota, A.A.B.; Oliveira, R.B.; Salvador, J.F.; Oliveira, M.A.P.

2011. Avaliação do desempenho de adjuvantes de calda para a pulverização aérea visando o controle de ferrugem da soja. Paper presented at: Simpósio Internacional de Tecnologia de Aplicação de Agrotóxicos, 5. Proceedings. FEPAF, Botucatu, p. 1-4.

Tormen N.R.; Silva, F.D.L.; Debortoli, M.P.; Uebel, J.D.; Fávera, D.D.; Balardin, R.S.

2012. Deposição de gotas no dossel e controle químico de Phakopsora pachyrhizi na soja. Revista Brasileira de Engenharia Agrícola Ambiental, 16, 7: 802-808.

Villalba, J.F.; Martins, D.; Costa, N.V.; Domingos, V.D. 2009. Deposição da calda de pulverização em cultivares de soja no estádio R1. Ciência Rural, 39, 6: 1738-1744. 